\title{
KOMBINASI BEDAH EKSISI, INJEKSI KORTIKOSTEROID INTRALESI, DAN GEL SILIKON PADA TATA LAKSANA KELOID DI CUPING TELINGA
}

\author{
Arif Widiatmoko, Herwinda Brahmanti, Tri Padesa Boco Pranowo \\ Departemen/SMF Ilmu Kesehatan Kulit dan Kelamin \\ FK Universitas Brawijaya/ RSUD dr. Saiful Anwar, Malang
}

\begin{abstract}
ABSTRAK
Keloid adalah proliferasi jaringan fibrosa jinak di kulit yang sering terjadi setelah trauma kulit dan sering timbul di cuping telinga. Terapi tunggal pada keloid menghasilkan angka kekambuhan yang tinggi. Kombinasi bedah eksisi, injeksi steroid intralesi, dan gel silikon akan mengurangi kekambuhan.

Kami melaporkan keloid yang bertambah besar di kedua cuping telinga seorang perempuan usia 21 tahun, sejak 4 tahun setelah berganti anting. Riwayat injeksi triamsinolon asetonid rutin setiap 2 minggu selama satu tahun. Benjolan di telinga kiri mengecil, tetapi benjolan di telinga kanan mengalami sedikit perbaikan. Tidak ada riwayat luka yang menjadi keloid di bagian tubuh yang lain. Pemeriksaan regio aurikularis dekstra menunjukkan nodul bulat lonjong soliter hiperpigmentasi dengan konsistensi padat kenyal dan diameter 1,3 cm. Bedah eksisi dilakukan pada keloid. Selain itu, dilakukan injeksi triamsinolon asetonid intralesi dan aplikasi gel silikon 1 minggu setelah eksisi. Evaluasi pasien pada bulan ke-8 tidak menunjukkan pertumbuhan keloid.

Kombinasi bedah eksisi, injeksi kortikosteroid intralesi, dan aplikasi gel silikon pada keloid cuping telinga dapat ini menekan kekambuhan dibandingkan dengan terapi injeksi kortikosteroid tunggal yang diberikan sebelumnya.

Kata Kunci : keloid, bedah eksisi, kortikosteroid intralesi, gel silikon
\end{abstract}

\section{COMBINATION OF EXCISION SURGERY, INTRALESIONAL CORTICOSTEROID INJECTION AND SILICONE GEL IN MANAGEMENT OF EARLOBE KELOID}

\section{Korespondensi:}

Jl. Jaksa Agung Suprapto no 2 Malang, Telp/Fax: 0341-340991,

HP: 08123388015

E-mail: arif280478@yahoo.com

\begin{abstract}
Keloid is benign fibrous tissue proliferation that usually results from skin trauma and commonlu found on earlobe. Single therapy for keloid has high recurrence rate. Combination therapy of excisional surgery, intralesional steroid injection and silicone gel apllication may decrease recurrence rate.

We reported 21 years old woman with enlarging keloid on both earlobe since 4 years ago after switching her earrings. She was previously treated with triamcinolone acetonide intralesional injection every 2 weeks since 1 year ago. The keloid on her left ear became smaller, but there was no significant change on her right ear. There was no history of keloid on other body part. Dermatological examination on right earlobe revealed solitary firm solid round oval hyperpigmented nodule with $1.3 \mathrm{~cm}$ on diameter. Excisional surgery was performed on keloid. Triamcinolone acetonide intralesion injection and topical silicone gel application were applied a week after excision. Patient evaluation after 8 months showed no keloid regrowth.

Combination of excision surgery, intralesion corticosteroid injection and silicone gel on this case of earlobe keloid suppressed recurrence of keloid compared with single therapy of intralesional corticosteroid injection given before.

Keywords : keloid, excision surgery, intralesion corticosteroid, silicone gel
\end{abstract}




\section{PENDAHULUAN}

Keloid adalah proliferasi jaringan fibrosa jinak yang dapat muncul secara spontan maupun akibat trauma di kulit. Bentuk klasik keloid berupa massa keras, menonjol, dan berkilat, disertai hiperpigmentasi. Pembentukan keloid biasanya menginvasi jaringan normal yang berdekatan dengan batas bekas luka. Keloid dapat mengenai semua ras. ${ }^{1}$

Keloid dapat muncul di semua bagian tubuh. Area yang sering timbul keloid adalah dada bagian anterior, lengan atas, bahu, dan paling sering di daun telinga bagian posterior yaitu lokasi dengan regangan yang minimal. Pertumbuhan keloid dapat menimbulkan rasa gatal dan nyeri serta bentuk yang tidak nyaman dipandang sehingga menyebabkan stres emosional. ${ }^{2,3}$

Sampai saat ini belum ada terapi yang efektif untuk keloid. Terdapat banyak pilihan metode terapi yang tersedia, namun belum menunjukkan hasil yang memuaskan karena tingkat rekurensinya yang tinggi. Pilihan terapi antara lain bedah eksisi, injeksi kortikosteroid intralesi, bedah beku, laser, radiasi dan kompresi mekanik. Bedah eksisi merupakan teknik yang paling sering digunakan karena dapat mengeliminasi lesi secara total, tetapi tetap ada kelemahan berupa angka rekurensi yang lebih dari $50 \%$. Untuk mengangkat lesi secara total dan mencegah rekurensi dibutuhkan kombinasi bedah eksisi dengan modalitas yang lain seperti injeksi kortikosteroid intralesi. ${ }^{4,5}$

Pada artikel ini dilaporkan sebuah kasus keloid pada cuping telinga kanan bagian belakang yang diterapi dengan kombinasi bedah eksisi, gel silicon, dan injeksi kortikosteroid intralesi.

\section{LAPORAN KASUS}

Seorang perempuan 21 tahun dengan benjolan di cuping telinga kanan sejak 4 tahun yang lalu setelah berganti anting. Keluhan diawali benjolan kecil di cuping telinga kanan dan kiri yang membesar, mengeras dan gatal. Riwayat injeksi triamsinolon asetonid rutin setiap 2 minggu selama 1 tahun yang lalu. Benjolan di telinga kiri mengecil, tetapi benjolan di telinga kanan hanya mengalami sedikit perubahan. Tidak pernah mengalami luka yang menjadi keloid di bagian tubuh yang lain dan pada keluarga. Pemeriksaan umum menunjukkan tanda vital normal pada regio aurikularis dekstra didapatkan nodus soliter hiperpigmentasi dengan konsistensi padat kenyal, berbentuk bulat oval dan diameter $1,3 \mathrm{~cm}$.

Diagnosis keloid pada pasien ditegakkan berdasarkan riwayat penyakit dan hasil pemeriksaan fisik. Bedah eksisi dilakukan pada keloid setelah edukasi dan tanda tangan persetujuan tindakan medik. Penilaian pra-operasi meliputi riwayat alergi terhadap obat bius, gangguan perdarahan, dan kondisi yang berhubungan dengan imunosupresi (Gambar 1).

Prosedur pembedahan diawali dengan tindakan aseptik, kemudian dilakukan injeksi larutan anestesi subkutan perilesi menggunakan campuran lidokain dengan epinefrin. Eksisi keloid dilakukan di dasar lesi dengan menggunakan skalpel nomor 15 dari tepi yang satu ke tepi yang lain dan dapat mungkin tidak melukai area kulit yang sehat sampai semua jaringan fibrosa terangkat. Luka eksisi kemudian ditutup dengan jahitan interuptus menggunakan benang monofilamen polipropilen non-absorbable ukuran 5/0 dengan tegangan minimal (Gambar 2).
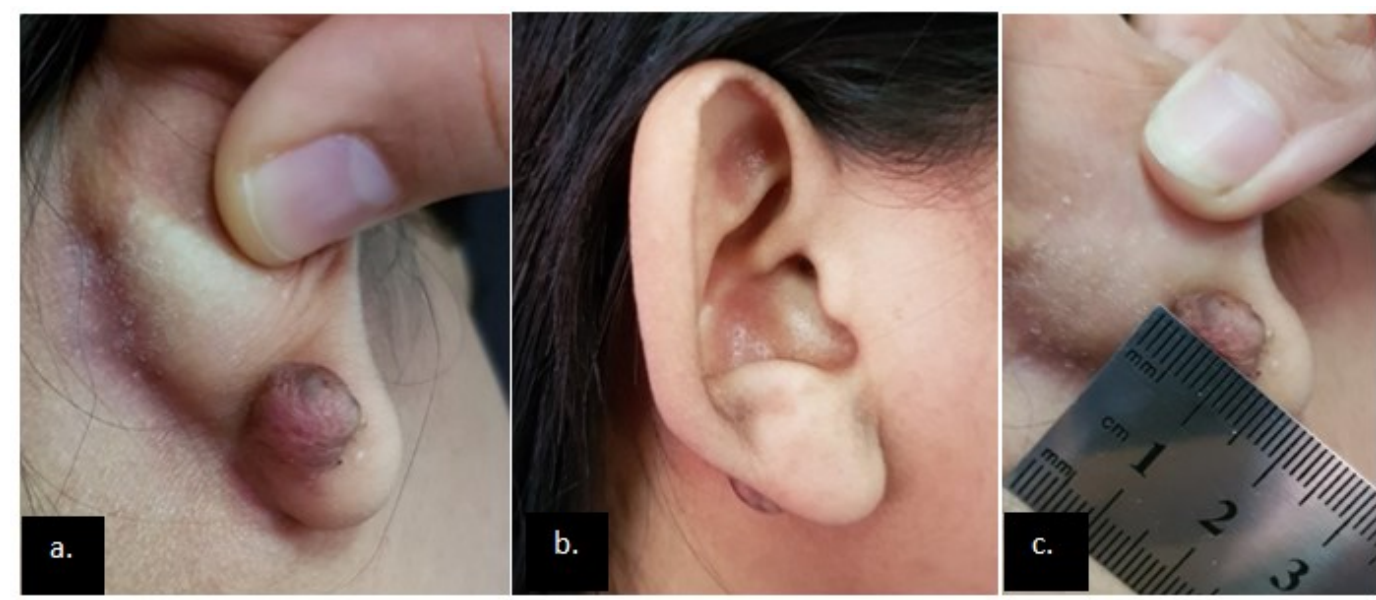

Gambar 1.(a) Nodul hiperpigmentasi, teraba padat kenyal, soliter, bentuk bulat oval (b) Bagian anterior tidak didapatkan adanya lesi (c) Diameter keloid 1,3 cm. 

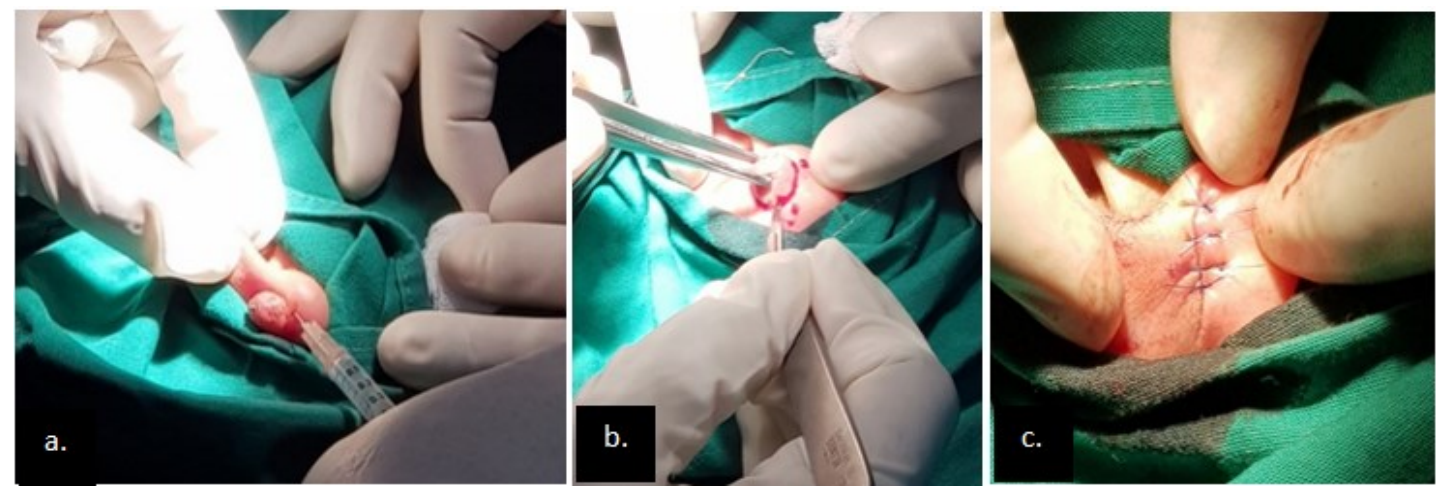

Gambar 2.(a) Injeksi anestesi subkutan perilesi (b) Eksisi di dasar lesi keloid (c) Jahitan interuptus

Pasien mendapat terapi natrium diklofenak $2 \times 50 \mathrm{mg}$ jika terasa nyeri di luka operasi dan salep gentamisin bila perban terbuka. Evaluasi luka pasca eksisi dilakukan satu minggu kemudian. Pemeriksaan histopatologi terhadap jaringan keloid menunjukkan potongan jaringan dilapisi epidermis normal. Pada dermis terdapat berkas jaringan kolagen yang tersusun tidak teratur. Kesimpulan gambaran histopatologi sesuai dengan keloid dalam pengobatan (Gambar 3).

Evaluasi satu minggu setelah eksisi nampak luka jahitan mengering dan tidak ada tanda-tanda infeksi.
Dilakukan pelepasan jahitan dan sebagian kecil luka belum tertutup sempurna. Tindakan injeksi triamsinolon asetonid $10 \mathrm{mg} / \mathrm{ml}$ intralesi dilakukan pada bekas luka eksisi untuk mencegah rekurensi. Pasien mendapat terapi gel silikon dua kali sehari. Evaluasi dalam 2 minggu setelah eksisi tampak luka menutup sempurna tanpa adanya jaringan granulasi. Evaluasi dilakukan setiap dua minggu untuk pemberian terapi injeksi triamsinolon asetonid intralesi selama empat siklus dan deteksi tanda rekurensi keloid (Gambar 4).
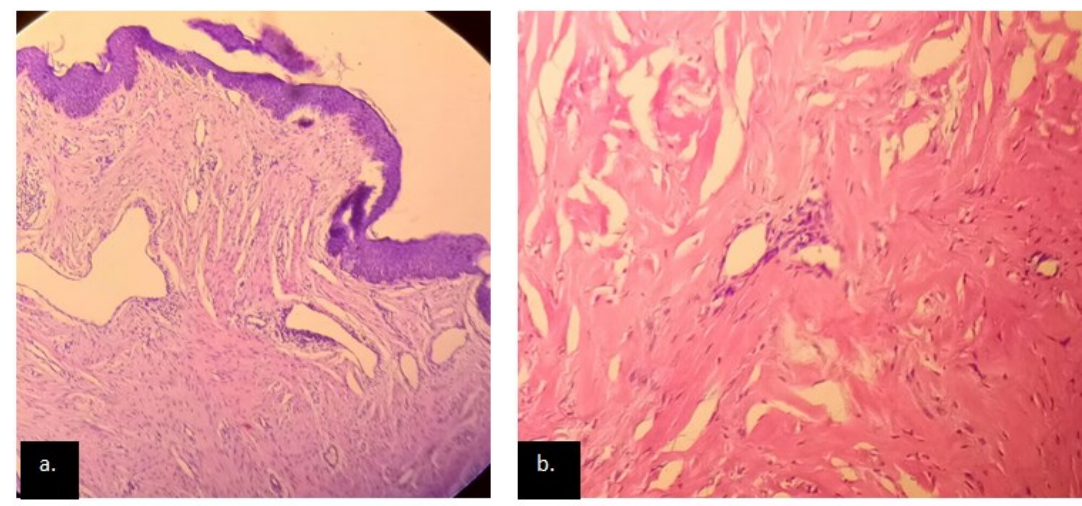

Gambar 3.(a) Epidermis tidak menunjukkan kelainan (40x) (b) Dermis tampak sebagian berkas berkas jaringan kolagen tersusun tidak teratur (100x) (Pewarnaan H\&E). Gambaran histopatologik jaringan keloid

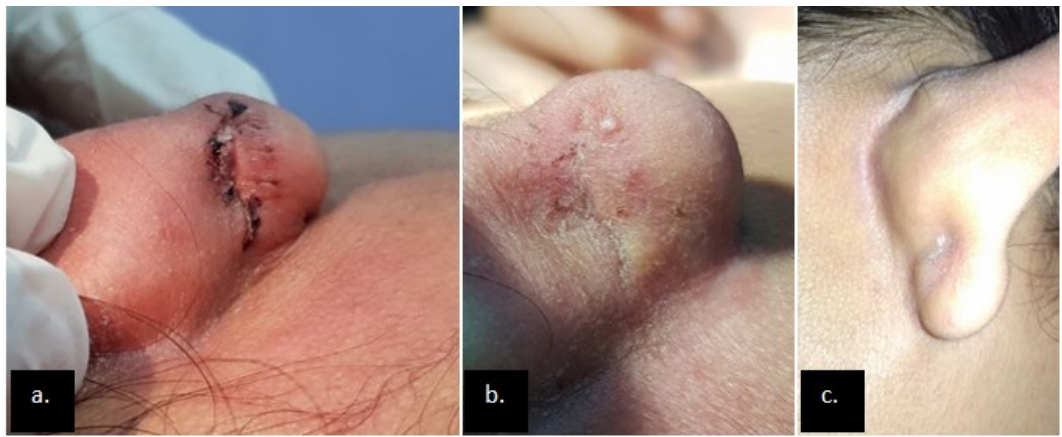

Gambar 4.(a) Luka setelah pelepasan jahitan nampak sebagian kecil tidak tertutup sempurna, krusta kering, dan tidak didapatkan infeksi sekunder (b) Evaluasi 2 minggu nampak luka tertutup sempurna (c) Evaluasi 8 bulan, tidak tampak pertumbuhan keloid 


\section{DISKUSI}

Keloid merupakan hiperproliferasi jinak kolagen dermis, sebagai respons jaringan yang berlebih terhadap trauma kulit. Keloid juga dapat muncul spontan tanpa riwayat trauma. Keloid biasanya terasa gatal dan nyeri. Meskipun jinak, keloid bisa meluas ke kulit normal yang berdekatan. ${ }^{6}$

Keloid lebih sering terjadi pada orang berkulit gelap meskipun dapat terjadi pada semua ras. Laporan kasus keloid pada albino belum ditemukan. Keloid cenderung muncul pada usia 10-30 tahun. Perempuan lebih banyak dibandingkan dengan laki-laki, diduga karena kecenderungan tindik pada tubuh. ${ }^{7,8}$ Insidens lebih tinggi pada saat pubertas dan kehamilan. Keloid memiliki faktor predisposisi genetik dengan pola penurunan autosomal dominan. ${ }^{9}$

Respons alami tubuh terhadap trauma jaringan adalah pembentukan skar. Proses penyembuhan luka terdiri atas tiga fase, yaitu fase inflamasi, proliferasi atau granulasi, dan remodelling atau maturasi. Ketika terdapat ketidakseimbangan antara fase anabolik dan katabolik pada pembentukan skar, hasil akhirnya berupa munculnya skar patologik. Terdapat dua tipe skar dengan pertumbuhan jaringan berlebih, yaitu skar hipertrofik dan keloid. ${ }^{9,10}$

Tidak seperti skar hipertrofik yang tumbuh sesuai batas luka awal meskipun meninggi, skar keloid tumbuh melebihi batas luka awal. Skar keloid berbentuk nodul keras dan umumnya tidak mengalami regresi spontan. Pasien sering merasakan gatal dan nyeri. Pada pasien ras Kaukasia, skar keloid disertai eritema dan teleangiektasi, sedangkan pada pasien berkulit gelap skar keloid dapat hiperpigmentasi. Area yang paling sering terkena adalah dada, bahu, punggung atas, belakang leher, pipi, dan daun telinga. Awalnya terdapat dugaan bahwa keloid hanya muncul di area dengan regangan kulit tinggi, akan tetapi telapak tangan dan kaki jarang muncul keloid sedangkan cuping telinga dimana area dengan regangan kulit minimal ternyata merupakan tempat paling umum munculnya keloid. Tidak seperti skar hipertrofik yang stabil namun dapat regresi setelah mencapai ukuran tertentu, keloid tidak mengalami regresi spontan dan dapat tumbuh terus menerus sepanjang waktu. ${ }^{11,14}$

Keloid menunjukkan peningkatan komposisi kolagen dan glikosaminoglikan dengan gulungan serabut kolagen terhialinisasi yang menebal sedangkan orientasi serabut kolagen pada jaringan skar normal sejajar dengan epidermis. Kolagen pada keloid nampak sebagai sebuah pita hialin tebal di dalam nodul eosinofilik yang tersusun di antara fibroblas padat dan dikelilingi pembuluh darah kecil. Metabolisme jaringan keloid terlihat lebih aktif dan mengonsumsi oksigen lebih banyak dibandingkan jaringan skar normal. Hal ini menunjukkan kondisi hipoksia pada fibroblas keloid. Potensi konsumsi oksigen yang tinggi dan difusi oksigen yang rendah mungkin berkontribusi pada patofisiologi pembentukan keloid. Beberapa peneliti melaporkan adanya sel mast dan histamin pada jaringan keloid, terutama pada perjalanan klinis awal yang dapat menjelaskan terjadinya pruritus pada lesi keloid. ${ }^{15-17}$

Terapi bedah eksisi tunggal menghasilkan tingkat rekurensi yang masih tinggi yaitu antara 50-100\% sehingga cara ini jarang digunakan sebagai terapi tunggal. Pembedahan jaringan skar yang berlebih untuk mengembalikan luka ke kondisi awal dan mencegah skar pasca operasi dapat dikurangi dengan terapi tambahan berupa injeksi intralesi kortikosteroid, radioterapi, kompresi, maupun imunomodulator. Pada penelitian kohort retrospektif tahun 2002 pada pasien keloid dengan modalitas kombinasi terapi eksisi diikuti dengan kombinasi terapi steroid dan radiasi atau steroid dan gel silikon, menghasilkan tingkat rekurensi yang lebih rendah dibandingkan kombinasi eksisi dan steroid saja. ${ }^{9,18}$

Kortikosteroid intralesi telah digunakan sebagai terapi utama keloid karena responsnya yang baik, mudah digunakan dan efek samping yang rendah. Keberhasilan terapi pada keloid yang berukuran besar telah dilaporkan pada injeksi triamsinolon intralesi. Kortikosteroid intralesi dapat menghambat pertumbuhan fibroblast dan meningkatkan pemecahan kolagen, selanjutnya akan mengurangi jumlah kolagen pada keloid. Efek samping kortikosteroid intralesi antara lain hipopigmentasi, atropi dan teleangiektasi. Pedoman umum untuk terapi intralesi diberikan dosis triamsinolon asetonid antara 10 dan $40 \mathrm{mg} / \mathrm{mL}$ dengan batas maksimum dosis $20 \mathrm{mg}$ setiap bulan. Sebagai terapi tambahan triamsinolon asetonid disuntikkan di area pasca operasi setiap 2 atau 3 minggu sebanyak 4 kali. Dosis maksimal yang dianjurkan setiap sesi adalah $5 \mathrm{~mL}$. Apabila pada area pasca operasi mulai muncul kembali lesi keloid, pemberian triamsinolon asetonid dapat diulangi. ${ }^{20,21}$

Produk gel silikon dikenal luas untuk terapi skar. Penelitian terbaru menunjukkan silikon mampu mencegah keloid sebanyak 80\% kasus setelah eksisi. Meskipun mekanisme kerja gel silikon yang pasti masih belum diketahui, produk silikon yang efektif harus dapat memberikan oklusi, hidrasi dan meningkatkan suhu pada skar. Silikon gel melunakkan, mengurangi ukuran skar, ertema, nyeri dan gatal. Silikon gel harus digunakan terus menerus untuk mendapatkan efek terapi yang baik, oleh karena itu kepatuhan pasien dapat menjadi masalah terutama bila skar terletak pada area yang mudah terlihat. Formulasi gel silikon dalam tube mudah mengering, oleh karena itu kurang efektif dibandingkan gel silikon dalam bentuk dressing pada satu penelitian. ${ }^{11,14}$

\section{SIMPULAN}

Telah dilaporkan kasus keloid pada perempuan usia 21 tahun di cuping telinga kanan bagian belakang. Diagnosis keloid ditegakkan berdasarkan riwayat penyakit, pemeriksaan dermatologis dan pemeriksaan histopatologis. Terapi kombinasi bedah eksisi, injeksi triamsinolone 
asetonid $10 \mathrm{mg} / \mathrm{ml}$ intralesi dan aplikasi gel silikon. Evaluasi 8 bulan setelah operasi menunjukkan hasil yang baik tanpa pertumbuhan keloid lagi.

\section{DAFTAR PUSTAKA}

1. Jones ME, McLane J, Adenegan R, Lee J, Ganzer CA. Advancing keloid treatment: a novel multimodal approach to ear keloids. Dermatol Surg. 2017;43:1164-9.

2. Jones ME, Hardy C, Ridgway J. Keloid management: A retrospective case review on a new approach using surgical excision, platelet-rich plasma, and in-office superficial photon X-ray radiation therapy. Advances in skin \& wound care. 2016;29:303-7.

3. Hunasgi S, Koneru A, Vanishree M, Shamala R. Keloid: A case report and review of pathophysiology and differences between keloid and hypertrophic scars. J Oral and Maxillofac Pathol. 2013;17:116-20.

4. Sharquie KE, Noaimi AA, Al-Karhi MR. Debulking of Keloid Combined with Intralesional Injection of 5Flurouracil and Triamcinolone versus Intralesional Injection of 5-Flurouracil and Triamcinolone. J Cosmet, Dermatol Scien and Applicat. 2014;4:85-91.

5. Narakula GK, Shenoy RK. A prospective clinical review of "multi model" approach for treating ear keloids. Indian J Plast Surg. 2008;41:2-7.

6. Kelly AP. Medical and surgical therapies for keloids. Dermatol Ther. 2004;17:212-8.

7. Viera $\mathrm{MH}$, Vivas AC, Berman B. Update on keloid management: clinical and basic science advances. Advances in Wound Care. 2012;1:200-6.

8. Jones ME, Hardy CJ, Ridgway JM. Head and neck keloid management: A retrospective early review on a new approach using surgical excision, platelet rich plasma and in office superficial photon X-ray radiation. Edorium J Otolaryngol. 2015;2:14-9.

9. Sobec R, Dobreanu C, Fodor L, Şomcutean A, Ţichil I, Cosgarea M. Ear keloids: a review and update of treatment options. Clujul Medical. 2013;86:313-7.
10. Wolfram D, Tzankov A, Pülzl P, Piza-Katzer HI. Hypertrophic scars and keloids - a review of their pathophysiology, risk factors, and therapeutic management. Dermatol Sur. 2009;35:171-81.

11. Chike-Obi CJ, Cole PD, Brissett AE. Keloids: pathogenesis, clinical features, and management. Seminars in Plastic Surgery. 2009;23:178-84.

12. Gauglitz GG. Management of keloids and hypertrophic scars: current and emerging options. Clin, Cosmet and Invest Dermatol. 2013;6:103-14.

13. Huang C, Murphy GF, Akaishi S, Ogawa R. Keloids and hypertrophic scars: update and future directions. Plastic and Reconstructive Surgery Global Open. 2013;1: e25

14. Robles DT, Berg D. Abnormal wound healing: keloids. Clin Dermatol. 2007;25:26-32.

15. Ichioka S, Ando T, Shibata M, Sekiya N, Nakatsuka T. Oxygen consumption of keloids and hypertrophic scars. Ann Plast Surg. 2008;60:194-7.

16. Sasaki A, Mueller RV, Xi G, Sipe R, Buck D, Hollinger J. Mast cells: an unexpected finding in the modulation of cutaneous wound repair by charged beads. Plastic and Reconstructive Surgery. 2003;111:1446-53.

17. Tripoli M, Cordova A, Melloni C, Zabbia G, Maggì F, Moschella F. The use of triamcinolone combined with surgery in major ear keloid treatment: a personal two stages approach. Europ J Plastic Surgery. 2015;38:205-10.

18. Lindsey WH, Davis PT. Facial keloids: A 15-year experience. Archives of Otolaryngol - Head \& Neck Surgery. 1997;123:397-400.

19. Lee NY, Song WK, Whang KK. A review of treatments of keloids with intramarginal surgical excision and postoperative irradiation to prevent recurrences. Ann Dermatol. 2004; 16:145-52.

20. Mafong EA, Ashinoff R. Treatment of hypertrophic scars and keloids: a review. Aesth Surg J.2000;20:114-21.

21. Kelly AP. Update on the management of keloids. Seminars in Cutaneous Medicine and Surgery. 2009;28:71-6. 